\title{
REFERENCES
}

1. Choni I. V., Kovalenko N. P. Rozrobka novoi emulsiinoi produktsii na osnovi roslynnoi syrovyny //Naukovyi visnyk PUET: Technical Sciences. - 2015. - №. 1 (28).

2. Yurchak V. H. y dr. Doslidzhennia hranulometrychnoho skladu tsilnozmelenoho pshenychnoho boroshna yak syrovyny dlia makaronnykh vyrobiv. - 2011.

3. Kholodchenko R. M. Oves holozernyi - tsinna zernova kultura //R.M. Kholodchenko $\$ [Elektronnyi resurs].- rezhym dos-tupu: www. sworld. com. ua/konfer26/851. pdf.

4. Moudry J. Quality and Market of Naked Oat. In: Proceedings Quality of grains - contemporary evaluating. Institute of Plant Production Praha - Ruzyne. 1995. - 273.

5. Welch, R. W. The Oat Crop: Production and Utilization. ed. Chapman and Hall, UK. 1995. pp. - 584.

6. Moudry J. The quality of naked oat//Cereals for human health and preventive nutrition. Session I. - 1998. rr. - 257.

7. Yurchenko K. S. Vykorystannia tradytsiinykh i netradytsiinykh vydiv syrovyny dlia vyrobnytstva bilkovo-zbyvnykh napivfabrykativ ozdorovchoho pryznachennia //Myr nauky y ynnovatsyi.-Vыpusk 2 (2). Tom 4.-Yvanovo. - 2015. - S. 13.

8. Podpriatov H.I., Skaletska L.F., Senkov A.M. Zberihannia i pererobka produktsii roslynnytstva. - K.: TsP Komprynt, 2010. $544 \mathrm{c}$.

9. Syrokhman I.V. Yakist i bezpechnist zernoboroshnianykh produktiv. Navchalnyi posibnyk [Tekst] / I.V. Syrokhman, T.M. Lozova. - K.: Tsentr navchalnoi literatury, 2006. - $384 \mathrm{~s}$.

10. Oshchypok I. M. Vykorystannia novykh kharchovykh dobavok z roslynnoi syrovyny u kharchovii promyslovosti / I. M. Oshchypok. // Visnyk Lvivskoi komertsiinoi akademii. Seriia tovaroznavcha. - 2015. - №15. - S. 77-81.

11. Hryshchenko A. M., Drobot V. I. Tekhnolohichni vlastyvosti bezghliutenovykh vydiv syrovyny //Naukovi pratsi ONAKhT. -2015. - T. 1. - №.46.

12. Sots S. M. Mozhlyvosti vykorystannia vivsa dlia stvorennia produktiv funktsionalnoho pryznachennia / S. M. Sots, I. O. Kustov. // Zbirnyk tsentru naukovykh publikatsii «Veles» za materialamy mizhnarodnoi naukovo-praktychnoi konferentsii: «Nauka v epokhu dysbalansiv». - K.: Tsentr naukovykh publikatsii.

Надійшла 27.02.2016. До друку 10.03.2016
Адреса для переписки:
вул. Канатна, 112, м. Одеса, 65039

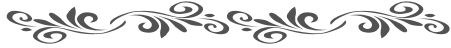

DOI:

УДК 612.397.23+577.16+613.2

А. П. ЛЕВИЦКИЙ ${ }^{1}$, д-р биол. наук, профессор,

И. В. ХОДАКОВ ${ }^{2}$, науч. сотруд., А. П. ЛАПИНСКАЯ ${ }^{2}$, канд. техн. наук, доцент

1 - ГУ «Институт стоматологии НАМН Украины»» (2. Одесса)

2 - Одесская начиональная академия пищевых технологий

\section{ВЛИЯНИЕ КОКОСОВОГО МАСЛА НА ЛИПИАНЫЙ ОБМЕН И МИКРОБИОЦЕНОЗ У ЭКСПЕРИМЕНТАЛЬНЫХ ЖИВОТНЫХ}

\footnotetext{
Аннотация. Целью настоящей работы стало определение влияния добавки кокосового масла на показатели липидного обмена и микробиоценоза в организме крыс, получавщих безжировой рачион.

Кокосовое масло, содержащее более 70 \% среднецепочечных жирных кислот, почти полностью лишено эссенииальных полиненасыщенных жирных кислот. Тем не менее, его рекомендуют для питания больных ожирением и атеросклерозом.

Опыты были проведены на 16 крысах линии Вистар, распределенных в 3 группы: 1 - интактные, 2 - получали безжировой рацион и 3 - получали безжировой раџион + 5 \% кокосового масла. Продолжительность эксперимента составила 31 день, ежедневно потребление корма составило 30 г на голову.

В гомогенате печени и в сыворотке крови определяли ферментативными методами содержание триглицеридов и холестерина, активность уреазы (маркер микробного обсеменения), лизоцима (показатель неспеиифического иммунитета), эластазы (маркер воспаления).

При скармливании крысам безжирового рациона, содержащего белок, углеводы, витамины и минеральные вещества в физиологических кониентрациях, с вводом 5 \% кокосового масла вместо 5 \% крахмала установлено, что оно увеличивает привесы на $38 \%$, повымает содержание триглииеридов на 18,4\%, холестерина на 63,1 \% и снижает активность лизоцима в печени (в 2,4 раза) и в сыворотке крови на 12,5\%, увеличивает активность эластазы в сыворотке крови (на 43 \%), что свидетельствует о гиперлипемии, снижении уровня неспецифического иммунитета и развитии системного воспаления. Эти данные указывают на нецелесообразность использования кокосового масла лииами, склонными к развитию ожирения, стеатоза печени и атеросклероза.
}

Ключевые слова: кокосовое масло, безжировой рацион, жировой обмен, гепатостеатоз, холестерин, дисбиоз, системное воспаление. 


\section{Введение}

В нашей предыдущей работе [1] было показано, что добавка 5 \% кокосового масла к безжировому рациону крыс увеличивает суточные привесы животных на 38 \%. Однако, осталось неясным, за счет чего увеличивается прирост живой массы. Не исключено, что наблюдаемый прирост происходит за счет увеличения отложения жира и возможных нарушений жирового обмена $[2,3]$. Более того, увеличение жира в организме, как правило, приводит к его отложению в печени (гепатостеатоз) и к развитию дисбиоза, эндотоксинемии и системного воспаления [4].

Целью настоящего исследования стало определение влияния добавок кокосового масла на состояние липидного обмена и микробиоценоза у крыс, получавших безжировой рацион. Выбор кокосового масла был обусловлен тем обстоятельством, что это масло не содержит ненасыщенных жирных кислот, в том числе, и незаменимых полиненасыщенных жирных кислот (ПНЖК) и поэтому образование мембранных фосфолипидов и эфиров холестерина возможно лишь за счет эндогенного биосинтеза этих кислот [5].

\section{Материалы и методы исследования.}

В эксперименте было использовано 16 белых крыс линии Вистар (самцы, 4 месяца), распределенных в 3 группы: 1-ая - норма (интактные), получали стандартный рацион вивария (6 крыс), 2-ая - получала безжировой рацион (БЖР) и 3-я получала БЖР, в котором 5 \% крахмала были заменены на 5 \% кокосового масла [1]. Все крысы получали по 30 г корма в день на одну голову. Продолжительность эксперимента составила 31 день. Умерщвление животных осуществляли под тиопенталовым наркозом (20 мг/кг) путем тотального кровопускания из сердца.

В гомогенате печени и в сыворотке крови определяли ферментативными методами содержание триглицеридов [6] и общего холестерина [7], а также активность уреазы (маркер микробного обсеменения) [8], лизоцима (показатель неспецифического иммунитета) [9] и активность эластазы (маркер воспаления) [10]. По соотношению относительных активностей уреазы и лизоцима рассчитывали степень дисбиоза по Левицкому [11].

\section{Результаты и их обсуждение.}

В табл. 1 представлены результаты определения содержания жира (триглицеридов) и общего холестерина $(\mathrm{OX})$ в печени и сыворотке крови крыс. Из этих данных видно, что у крыс на БЖР увеличивается содержание триглицеридов (ТГ) в печени, которое еще больше возрастает при введении кокосового масла. В сыворотке крови содержание ТГ достоверно (почти в 2 раза) возрастает при вводе в БЖР кокосового масла. Аналогичная ситуация наблюдается и с общим холестерином, уровень которого значительно возрастает при вводе в БЖР 5 \% кокосового масла.

Эти данные свидетельствуют о развитии гиперлипидемии (увеличение ТГ и ОХ в сыворотке крови) и гепатостеатоза (увеличение ТГ и ОХ в печени) при скармливании крысам кокосового масла.

Возможно, это объясняется дефицитом полиненасы-
Таблица 1

Влияние кокосового масла на содержание липидов в печени и в сыворотке крови крыс, получавших БЖР в течение 31 дня

\begin{tabular}{||l||c|c||}
\hline Группы & $\begin{array}{c}\text { Триглицериды, } \\
\text { ммоль/кг(л) }\end{array}$ & $\begin{array}{c}\text { Холестерин, } \\
\text { ммоль/кг(л) }\end{array}$ \\
\hline \hline \multicolumn{3}{|c|}{ Печень } \\
\hline \hline 1. Норма & $8,5 \pm 0,3$ & $5,11 \pm 0,25$ \\
\hline \hline 2. БЖР & $11,4 \pm 0,6$ & $5,47 \pm 0,48$ \\
& $\mathrm{p}<0,05$ & $\mathrm{p}>0,3$ \\
\hline \hline 3. БЖР+ & $13,5 \pm 0,8$ & $7,92 \pm 0,56$ \\
кокосовое & $\mathrm{p}<0,01$ & $\mathrm{p}<0,01$ \\
масло & $\mathrm{p}_{1}<0,05$ & $\mathrm{p}_{1}<0,05$ \\
\hline \hline \multicolumn{3}{|c|}{ Сыворотка крови } \\
\hline \hline 1. Норма & $1,16 \pm 0,11$ & $1,31 \pm 0,05$ \\
\hline \hline 2. БЖР & $1,03 \pm 0,17$ & $1,08 \pm 0,03$ \\
& $\mathrm{p}>0,3$ & $\mathrm{p}<0,05$ \\
\hline \hline 3. БЖР+ & $2,02 \pm 0,34$ & $1,79 \pm 0,13$ \\
кокосовое & $\mathrm{p}<0,05$ & $\mathrm{p}<0,01$ \\
масло & $\mathrm{p}_{1}<0,05$ & $\mathrm{p}_{1}<0,001$ \\
\hline
\end{tabular}

Таблица 2

Влияние кокосового масла на активность уреазы и лизоцима в печени и в сыворотке крови крыс, получавших БЖР в течение 31 дня

\begin{tabular}{||l||c||c||}
\hline \multicolumn{1}{||c|}{ Группы } & $\begin{array}{c}\text { Уреаза, } \\
\text { нкат/кг(л) }\end{array}$ & $\begin{array}{c}\text { Лизоцим, } \\
\text { ед/кг(л) }\end{array}$ \\
\hline \hline \multicolumn{3}{|c||}{ Печень } \\
\hline \hline 1. Норма & $288 \pm 95$ & $32 \pm 4$ \\
\hline \hline 2. БЖР & $404 \pm 127$ & $12 \pm 2$ \\
& $\mathrm{p}>0,05$ & $\mathrm{p}<0,05$ \\
\hline \hline 3. БЖР+ & $99 \pm 11$ & $5 \pm 1$ \\
кокосовое & $\mathrm{P}<0,05$ & $\mathrm{p}<0,01$ \\
масло & $\mathrm{p}_{1}<0,05$ & $\mathrm{p}_{1}<0,05$ \\
\hline \hline \multicolumn{3}{|c||}{ Сыворотка крови } \\
\hline \hline 1. Норма & $1,40 \pm 0,25$ & $107 \pm 9$ \\
\hline \hline 2. БЖР & $0,66 \pm 0,19$ & $88 \pm 7$ \\
& $\mathrm{p}<0,05$ & $\mathrm{p}>0,05$ \\
\hline \hline 3. БЖР+ & $1,42 \pm 0,33$ & $77 \pm 3$ \\
кокосовое & $\mathrm{p}>0,6$ & $\mathrm{p}<0,05$ \\
масло & $\mathrm{p}_{1}<0,05$ & $\mathrm{p}_{1}>0,05$ \\
\hline \hline
\end{tabular}

щенных жирных кислот, без которых невозможен биосинтез мембранных и транспортных фосфолипидов, которые необходимы для образования липопротеидов, переносящих жиры от печени в рабочие органы [12].

В таблице 2 представлены результаты определения активности уреазы и лизоцима в печени и в сыворотке крови крыс. Как видно из этих данных, при БЖР увеличивается (однако, $\mathrm{p}>0,05)$ активность уреазы в печени, свидетельствующая об увеличении микробной обсемененности этого органа, и достоверно снижается активность уреазы в сыворотке, что указывает на задержку в печени поступающих из кишечника бактерий. Ввод кокосового масла снижает активность уреазы в печени, однако увеличивает ее в сыворотке. Напротив, активность лизоцима значительно (в 2-6 раз) снижается в печени у крыс, полу- 


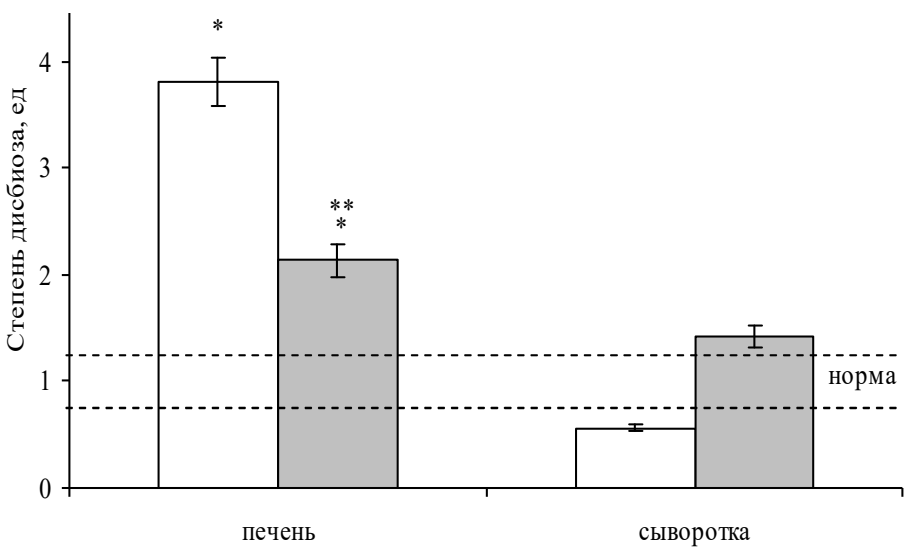

口БЖР чБЖР+кокосовое масло

\section{Рис. 1 - Влияние кокосового масла на степень дисбиоза у крыс, получавших БЖР $(*-p<0,05$ в сравнении снормой; **-p<0,05 в сравнении с БЖР)}

Таблица 3

Влияние кокосового масла на активность эластазы в печени и в сыворотке крови крыс, получавших БЖР в течение 31 дня

\begin{tabular}{||l||c|c||}
\hline Группы & $\begin{array}{c}\text { Печень, } \\
\text { нкат/кг }\end{array}$ & $\begin{array}{c}\text { Сыворотка } \\
\text { крови, нкат/л }\end{array}$ \\
\hline \hline 1. Норма & $306 \pm 26$ & $133,9 \pm 6,9$ \\
\hline \hline 2. БЖР & $308 \pm 17$ & $122,0 \pm 5,7$ \\
& $\mathrm{p}>0,7$ & $\mathrm{p}>0,05$ \\
\hline \hline 3. БЖР+ & $283 \pm 22$ & $174,5 \pm 18,0$ \\
кокосовое & $\mathrm{p}>0,3$ & $\mathrm{p}<0,05$ \\
масло & $\mathrm{p}_{1}>0,3$ & $\mathrm{p}_{1}<0,05$ \\
\hline
\end{tabular}

чавших БЖР или БЖР с добавкой кокосового масла. В сыворотке крови активность лизоцима достоверно снижается лишь у крыс, получавших БЖР с добавкой кокосового масла.

Рассчитанная степень дисбиоза показана на рисунке. Как видно, БЖР значительно увеличивает степень дисбиоза в печени за счет снижения активности лизоцима. Добавка кокосового масла снижает степень дисбиоза в 1,8 раза, однако не возвращает ее к норме. В сыворотке крови изменения показателя степени дисбиоза недостоверны.

В таблице 3 представлены результаты определения активности эластазы - протеолитического фермента лейкоцитарного происхождения, являющегося биохимическим маркером воспаления [10]. Из этих данных видно, что активность эластазы в печени существенно не изменяется, однако в сыворотке крови она достоверно возрастает у крыс, получавших кокосовое масло, что может свидетельствовать о развитии системного воспаления [13].

Таким образом, можно констатировать, что кокосовое масло вызывает развитие ожирения, о чем свидетельствуют следующие данные:

1. Увеличение суточного прироста живой массы на $38 \%$ [1]; $18,5 \%$;

2. Увеличение содержания жира в печени на

3. Почти 2-кратное увеличение жира в сыворотке крови.

Принимая во внимание увеличение содержания холестерина в печени на 44,8 \% и в сыворотке крови на 65,7 \%, можно говорить о нарушении в целом липидного обмена, что может создать базу для развития атеросклероза. Наши данные говорят о том, что нужно очень взвешено подходить к рекомендациям некоторых авторов о диетическом применении кокосового масла [14]. Важно также отметить, что нарушения липидного обмена приводят к существенному снижению уровня неспецифического иммунитета в печени, что обусловливает развитие системного воспаления, играющего существенную роль в патогенезе атеросклероза 13].

\section{Выводы}

1. Кокосовое масло вызывает развитие гиперлипидемии и гепатостеатоза.

2. Кокосовое масло снижает уровень неспецифического иммунитета и вызывает развитие системного воспаления.

3. По-видимому, целесообразно воздержаться от употребления кокосового масла в качестве диетического продукта.

1. Левицкий А. П. Кокосовое масло увеличивает привесы животных на безжировом рационе / А. П. Левицкий, И. В. Ходаков, Е. М. Шарабаева, Н. Г. Милева, А. Г. Кучерук, Л. А. Гринченко, М. Р. Гуиу // Зернові продукти і комбікорми. - 2015. - № 4. $-C$.

2. Turnbangh P. J. An obesity-associated gut microbiome with increased capacity for energy harvest / P. J. Turnbangh, R. E. Ley, M. A. Mahowald [et al.] // Nature. - 2006. - v. 444, № 21/28. - P. 1027-1031.

3. Cani P. D. Changes in gut microbiona control metabolic endotoxemia-induced inflammation in high-fat diet-induced obesity and diabetes in mice / P. D. Cani, R. Biliboni, C. Knauf [et al.] // Diabetes. - 2008. - 57(6). - P. 1470-1481.

4. Browning J. D. Molecular mediators of hepatic steatoses and liver injury / J. D. Browning, J. D. Horton // J. Clin. Invest. - 2004. v. 114, № 1. - P. 147-152.

5. Ариновский А. В. Физиология среднецепочечных жирных кислот. Физиологические особенности метаболизма и применение в клинике / А. В. Ариновский, В. Н. Титов // Клиническая лабораторная диагностика. - 2013. - № 6. -C. 3-10.

6. Інструкиія до набору реактивів для визначення триглічеридів у сироватиі і плазмі крові ензиматичним колориметричним методом / ТУ У 24.4-24607793-020-2003.

7. Холестерин. Ферментативно-фотометрический метод с холестерин-оксидазой (пероксидазой) / PT МД11-15796482001:2003.

8. Гаврикова Л. М. Уреазная активность ротовой жидкости у больных с острой одонтогенной инфекичей челюстно-лицевой области / Л. М. Гаврикова, И. Т. Сегень // Стоматология. - 1996. - Спец. выпуск. - С. 49-50.

9. Левицкий А. П. Лизоцим вместо антибиотиков / А. П. Левицкий. - Одесса: КП ОГТ, 2005. - 74 с.

10. Левиикий А. П. Методы определения активности эластазы и ее ингибиторов: методические рекомендаиии / А. П. Левицкий, А. В. Стефанов. - К.: ГФЦ, 2002. -15 c. 
11. Пат. на корисну модель 43140 Украӥна, МПК (2009) G 01 N 33/48. Спосіб оиінки ступеня дисбіозу (дисбактеріозу) органів $i$ тканин / Левицький А.П., Деньга О.В., Селіванська І.О [та ін.]. - № и 2008 15092; заявл. 26.12.2008; опубл. 10.08.2009, Бюл. № 15.

12. Титов В. Н. Олеиновая жирная кислота, олеиновые, линолевые и линоленовые липопротеины низкой плотности / В. Н. Титов // Клиническая лабораторная диагностика. - 2006. - № 6. - С. 3-13.

13. Титов В. Н. Экзогенные и эндогенные патологические факторы (патогены) как причина воспаления / В. Н. Титов // Клиническая лабораторная диагностика. - 2004. - № 5. - С. 3-10.

14. Титов В. Н. Среднецепочечные жирные кислоты: содержание в пище, физиология, особенности метаболизма и применения в клинике / В. Н. Титов // Вопросы питания. - 2012. - m. 81, № 6. - С. 27-36.

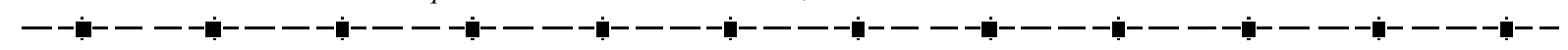

A. P. Levitsky ${ }^{1}$, doctor of biol. sciences, professor, I. V. Khodakov ${ }^{1}$, stuff scietist ,

A. P. Lapinskaya ${ }^{2}$, candidate of techn. sciences, associate professor

$1-S E$ «The Institute of Stomatology of the NAMS», Odessa

2 - Odessa National Academy of Food Technologies, Odessa

\title{
INFLUENCE OF COCNUT OIL ON LIPID METABOLISM AND MICROBIOCENOSIS IN EXPERIMENTAL ANIMALS
}

\begin{abstract}
The aim of this work was to determine the effect of coconut oil supplement on lipid metabolism and microbiocenosis in rats fed with a fat-free diet.

Coconut oil contains more than $70 \%$ of medium chain fatty acids and almost no essential polyunsaturated fatty acids. Nevertheless, it is recommended for patients with obesity and atherosclerosis.

Experiments were conducted on 16 Wistar rats, which were distributed in 3 groups: 1 - intact, 2 - received lean diet, and 3 - lean diet plus 5\% of coconut oil. The duration of the experiment was 31 days, a daily food intake was $30 \mathrm{~g}$
\end{abstract} per rat.

In the liver homogenate and serum there were determined triglycerides and cholesterol, urease activity (a marker of microbial contamination), lysozyme (nonspecific immunity), elastase (a marker of inflammation) using enzymatic methods.

Feeding rats with a lean diet containing protein, carbohydrates, vitamins and minerals in physiological concentrations, and plus 5\% of coconut oil instead of 5\% of starch it was found that the weigh gain has been increased by $38 \%$, the triglyceride content by $18.4 \%$, and cholesterol by $63.1 \%$. The activity of lysozyme was increased by $2.4-$ fold in the liver and by $12.5 \%$ in the serum. The activity of elastase in the serum was increased (43\%) indicating hyperlipemia, reduced nonspecific immunity and development of systemic inflammation. These data indicate the inappropriateness of coconut oil for individuals prone to obesity, hepatic steatosis and atherosclerosis.

Keywords: coconut oil, fat-free diet, fat metabolism, hepatic steatosis, cholesterol, dysbiosis, systemic inflammation.

\section{REFERENCES}

1. Levitskiy A. P., Khodakov I. V., Sharabaeva E. M., Mileva N. G., Kucheruk A. G., Grinchenko L. A., Gutsu M. R. Coconut oil increases weigh gains of animals on a lean diet. Cereal products and animal food. - 2015. - № 4. - P.

2. Turnbangh P. J., Ley R. E., Mahowald M. A. [et al.]. An obesity-associated gut microbiome with increased capacity for energy harvest. Nature. - 2006. - v. 444, № 21/28. - P. 1027-1031.

3. Cani P. D., Biliboni R., Knauf C. [et al.]. Changes in gut microbiona control metabolic endotoxemia-induced inflammation in highfat diet-induced obesity and diabetes in mice. Diabetes. -2008 . - 57(6). - P. 1470-1481.

4. Browning J. D., Horton J. D. Molecular mediators of hepatic steatoses and liver injury. J. Clin. Invest. - 2004. - v. 114, № 1. - P. 147-152.

5. Arinovskiy A. V., Titov V. N. Physiology of medium chain fatty acids. Physiological characteristics of metabolism and clinical application. Clinical Laboratory Diagnostics. - 2013. - № 6. - P. 3-10.

6. The instruction to the set of reagents for the determination of triglycerides in blood serum and plasma with enzymatic colorimetric method / TU U 24.4-24607793-020-2003.

7. Cholesterol. Enzymatic-photometric method with cholesterol-oxidase (peroxidase) / RT MD11-15796482-001:2003.

8. Gavrikova L. M., Segen I. T. Urease activity of oral liquid in patients with acute odontogenic infection of maxillo-facial part. Stomatologiya. - 1996. - The extra issue. - P. 49-50.

9. Levitsky A. P. Lysozyme instead of antibiotics. Odessa: KP OGT, 2005. - 74 p.

10. Levitsky A. P., Stefanov A. V. The methods of the determination of the activity of elastase and its inhibitors: method guidelines. Kiev: GFK, 2002. -15 p.

11. Levitsky A. P., Denga O. V., Selivanskaya I. A. [et al.]. The method of estimation of the degree of dysbiosis (dysbacteriosis) of organs and tissues. Patent of Ukraine 43140. IPC (2009) G01N 33/48. Application number u 200815092. Date of filling: 26.12.2008. Publ.: 10.08.2009. Bul. № 15.

12. Titov V.N. Oleic fatty acid, oleic, linolic, linolenic and low-density lipoproteins. Clinical Laboratory Diagnostics. 2006; 6: 3-13.

13. Titov V. N. Exogenous and endogenous pathological factors (pathogens) as the inflammation cause. Clinical Laboratory Diagnostics. - 2004. - № 5. - P. 3-10.

14. Titov V. N. Medium chain fatty acids: the content in food, physiology, metabolic features and application in clinics. Nutrition questions. -2012 . - v. 81, № 6. - P. 27-36.

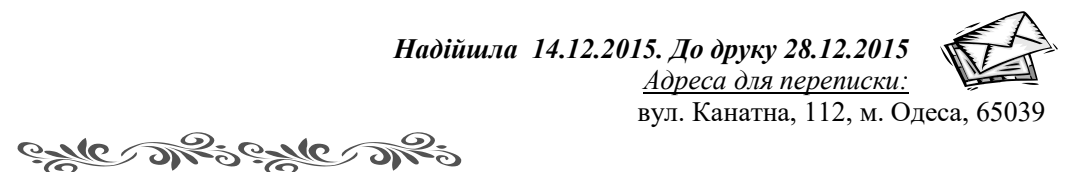

